\title{
Technical Analysis of Influence of Special Treatment on Water Ballast Treatment using Active Carbon on Vessel and Environment
}

\author{
Aguk Zuhdi M. Fathallah ${ }^{1}$, Fachrul Hidayat Husein ${ }^{2}$
}

\begin{abstract}
The ballast water exchange can be harmful microorganisms that shifts has been be a predator for the ecosystem of the intended recipients. To prevent this, IMO issued several rules regarding the disposal of water ballast, ballast water i.e. issued a ship must be in clean condition or there should be a treatment first before being dumped. Various alternative treatments ever used to be able to satisfy this rule. In this final task, developed one of the alternative treatment with using chemicals activated carbon with the object of study of ship cruise route with SINAR SUMBA Singapore - Surabaya and time planning is designed for 12 hours. The selection of the method of test samples conducted in the laboratories chosen to know the applications the use of activated carbon to water ballasts of Surabaya and Singapore is in compliance with the specified standards. Then the next design planning systems or designs are suitable for use on the ship. From the results of the study shoitd that by using activated carbon- filtration, activated carbon the water turned out to be able to reduce the number of microorganisms such as E. Coli, Vibrio Cholerae, and Intestinal Enterococci in accordance with the IMO standards. Based on the results of the laboratory activated carbon filter design then the water ballast can be realized.
\end{abstract}

Keywords - water ballast, water ballast treatment, active carbon, IMO.

\section{INTRODUCTION}

$\mathrm{B}$ allast is one system in a ships which is very important. Ships require ballast for the ship's stability. Ballast water is usually inserted into the ballast tanks in the ship when the ship was not loaded. And when the ship is not loaded, the ballast water has been be removed from the ship ballast tanks [1].

Exchange of ballast water carried by ships from one port to another port pose a problem. Ballast water brought a ship can carry marine microorganisms, bacteria, pathogens that live in the home environment and disposed of in a new environment. The sea water is sucked by the pump into the ballast tank vessel during the voyage, generally consists of water mixed with various types of marine microorganisms, sediment, and rocks [2]. Marine microorganisms are carried on and switched through ship ballast tanks has been be able to survive in new waters, but life has been change and tend to be predatory. This can cause damage to the food chain and the environment in new waters. So when the ballast water transport need special attention so that the control and prevention of marine microorganisms exchanges against unwanted [2].

In application, the handling of ballast water divided into two ballast water exchange at the time of sailing (ballast water exchange) and a handling system which is built on the boat (on board treatment).

Methods flow through, emptying and filling and water exchanger is that many do to ship safety risks and also has a low effectiveness.

Aguk Zuhdi M. Fathallah is with Department of Marine Engineering, Institut Teknologi Sepuluh Nopember, Surabaya 60111, Indonesia. Email: fathalaz@its.ac.id

Fachrul Hidayat Husein is with Department of Marine Engineering, Institut Teknologi Sepuluh Nopember, Surabaya 60111, Indonesia
Therefore, the study was performed in the ballast water treatment modification by applying activated carbon to the ship [1].

Various kinds of ballast water treatment system has been developed, but if it want to refer to the function of the remaining time is still classified as less effective and efficient. According to Yolanda [2], selection of the use of activated carbon is due to several advantages that are not available on other systems, including:

1. Activated carbon is one of the best tools that can be used to reduce the risk to human health at low cost.

2. Activated carbon is an effective adsorbent is because the shape of the pores are large. This provides a relatively large surface area to the actual size carbon particles.

3. Safe to use.

4. Simplicity on maintenance.

\section{METHOD}

Once a problem is already known, then the next is the study of literature. Which at this stage, searched and studied about the problems that exist, soclear what should be done in this thesis in order these problems can be solved. Studies literature can be done by reading the paper or journal dealing with problems to be solved. Of the steps that have been determined, it conducted mathematical calculations based on the reference of the IMO Interim Performance Guidance and has been be compared with experiments.

In this research after receiving results ballast system without active carbon and ballast system with active carbon treatment. The microorganism has been different, and amount of microorganism has been be reducing with active carbon treatment.

\section{RESULTS AND DISCUSSION}

Based IMO rules, the microorganism to be observed is the amount of E. coli bacteria, intestinal enterococci, and 
TABLE 1.

OBSERVATION MICROORGANISM BEFORE AND AFTER TREATMENT

\begin{tabular}{|c|c|c|c|c|c|c|}
\hline \multirow[t]{2}{*}{$\begin{array}{l}\text { Named of } \\
\text { bacteria }\end{array}$} & \multicolumn{3}{|c|}{ before Treatment } & \multicolumn{3}{|c|}{ After treatment } \\
\hline & E. Coli & $\begin{array}{c}\text { Vib. } \\
\text { Cholera e }\end{array}$ & $\begin{array}{c}\text { Int. } \\
\text { Enteroc } \\
\text { occi }\end{array}$ & E. Coli & $\begin{array}{c}\text { Vib. } \\
\text { Cholerae }\end{array}$ & $\begin{array}{c}\text { Int. } \\
\text { Enteroc } \\
\text { occi }\end{array}$ \\
\hline Surabaya & $\begin{array}{c}+84 \\
\text { koloni }\end{array}$ & $\begin{array}{c}+68 \\
\text { koloni }\end{array}$ & Positif & +5 koloni & $\begin{array}{c}+12 \\
\text { koloni }\end{array}$ & Positif \\
\hline Singapura & $\begin{array}{c}+13 \\
\text { koloni }\end{array}$ & $\begin{array}{l}+67 \\
\text { koloni }\end{array}$ & Positif & +4 koloni & Negatif & Positif \\
\hline
\end{tabular}

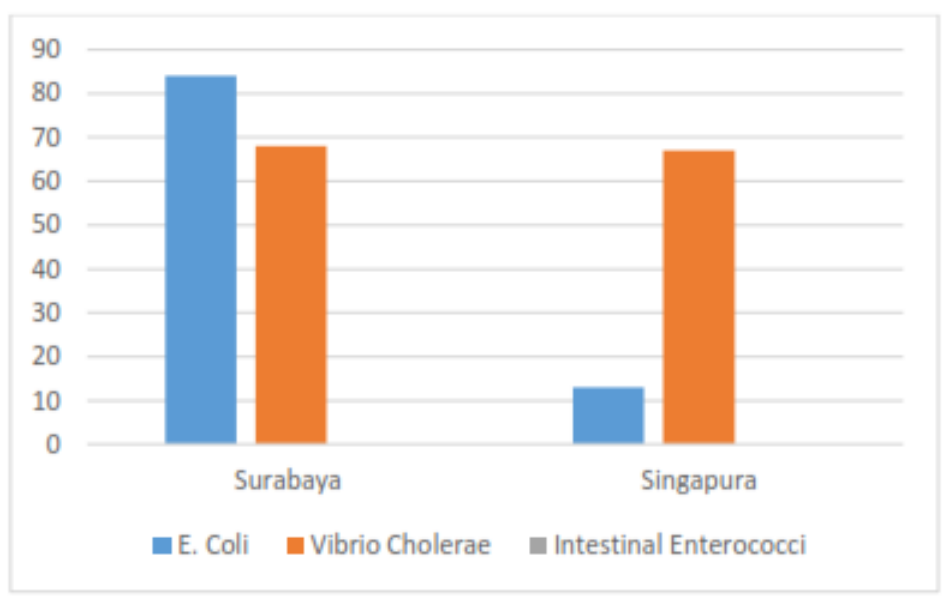

Figure. 1. Two sampling sites that ballast water route cruise ship Surabaya and Singapore

Vibrio cholerae. The data obtained during data retrieval is as follows in Table 1.

IMO regarding the number of each colony of E. coli bacteria is less than 250 colonies, Vibrio cholerae is less than 1 colony, and Intestinal Enterococci less than 100 colonies. If seen from the table and graph the number of E. coli bacteria prior to getting special treatment meets the standards. Then for Vibrio cholerae before getting special treatment is still not meet the standards. And to Intestinal Enterococci content is still positive, but according to the test results of lab samples of an unknown number.

From the diagram 1, for two sampling sites that ballast water route cruise ship Surabaya and Singapore seem reduced the number of bacteria after getting special treatment.

IMO standard rules regarding the number of each colony of E. coli bacteria is less than 250 colony meets the standards of the previous number of bacteria colonies was reduced to 845 colony. Then Vibrio cholerae is less than 1 colony still do not meet the standards for ballast water Surabaya because they contained bacteria but for Singapore ballast water meets the standards for not contained bacteria or negative. And Intestinal
Enterococci less than 100 colonies still identified number of bacteria, but when vieitd from the total number of bacteria, all bacteria proved to be reduced. Table 2, shows of total number of bacteria before and after treatment.

After getting the results of the laboratory test sample, then the next step is to plan a ballast water treatment system that has been be installed on the ship.

From these data, it was found the number of microorganisms that have been drained activated carbon is the purpose of research.

Calculation of active carbon usage. By taking ballast water samples each 1.5 liter by using activated carbon as much as 10 grams, it can be applied to vessels with ballast specifications as follows:

\section{Ship's name: SINAR SUMBA}

Ship type: Container Vessel

Flag: Port of Registry SINGAPORE: SINGAPORE

Total ballast capacity: $7913.62 \mathrm{~m} 3$

Number of segregated ballast tanks: 20

TABLE 2.

TOTAL NUMBER OF BACTERIA BEFORE AND AFTER TREATMENT

\begin{tabular}{ccc}
\hline Number of bacteria & $\begin{array}{c}\text { before } \\
\text { treatment }\end{array}$ & $\begin{array}{c}\text { After } \\
\text { treatment }\end{array}$ \\
\hline Surabaya & $1.9 \times 109 \mathrm{cfu} / \mathrm{ml}$ & $5.5 \times 108 \mathrm{cfu} / \mathrm{ml}$ \\
\hline Singapore & $8.5 \times 108 \mathrm{cfu} / \mathrm{ml}$ & $2 \times 108 \mathrm{cfu} / \mathrm{ml}$ \\
\hline
\end{tabular}




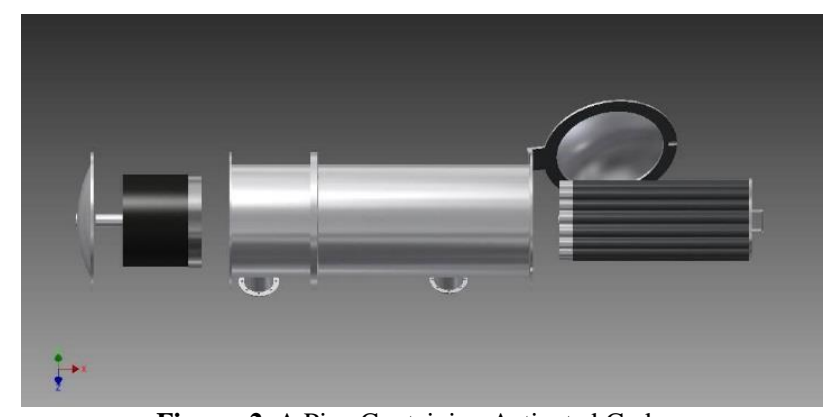

Figure. 2. A Pipe Containing Activated Carbon

Number of ballast water pumps: 2

Capacity of ballast water pumps (each): 330

Planning a pipe containing activated carbon with a length of pipe $70 \mathrm{~cm}$ and $40 \mathrm{~cm}$ diameter pipe then obtained $352 \mathrm{~cm} 3$ volume or 0.4 liters or 400 gr. And a pipe containing activated carbon which are planned for a total of 32 pieces, the total active carbon is required as many as 12,800 ounces or $12.8 \mathrm{~kg}$ or $13 \mathrm{~kg}$ by using active carbon produced by the plant. See at Figure 2 .

But there are other ways besides using a pipe containing activated carbon which uses activated carbon fiber filter according to the drawings 4:15. In the planning of water passes through the inlet and is filtered using a filter as the first treatment.

And then pass through the activated carbon fiber filter which amounted to 32 pieces a second treatment. Designed as a cartridge that can be replaced when usage reaches the maximum limit.

After that the filtered water passing through activated carbon filter can be disposed of in accordance with IMO standards. The specifications of the activated carbon fiber filter as follows:

\section{Filter length: $75 \mathrm{~cm}$}

Filter diameter: $3.8 \mathrm{~cm}$

Highest working pressure: $0.4 \mathrm{Mpa}$

Velocity: $4 \mathrm{~m} / \mathrm{s}$

The document of the ship ballast water management plan SINAR SUMBA known capacity of the pumps installed in the ship. On the basis of the capacity of the pumps, then the time required to conduct ballast water treatment can be known.

Using the formulation:

$$
\begin{aligned}
& \mathrm{Q}=\mathrm{V} / \mathrm{t} \\
& \mathrm{t}=\mathrm{V} / \mathrm{Q} \\
& \mathrm{t}=7913,62 / 660 \\
& \mathrm{t}=12 \text { hour }
\end{aligned}
$$

So, the time required to make the handling of ballast water in ships is 12 hour.

\section{CONCLUSION}

Based on research that has been done on two samples derived from two ports, namely Surabaya and Singapore from the ship SINAR SUMBA it can be concluded as follows:

1. To use activated carbon in the vessel may use a filtration system that can function as a cartridge. Hoitver, filter the water using activated carbon. In this trial dose use of activated carbon is used as much as 10 grams are used to reduce the number of microorganisms contained in ballast water as much as 1.5 liters, with a time of screening, carried out for 8 hours.

2. IMO standards which define discharge clean ballast water can be met by using a filtering system based activated carbon.

\section{REFERENCES}

[1] Captain Nadeem Anwar. "Ballast Water Management" - 3rd Edition. 2011.

[2] Yolanda. "ECOGREENSHIP - Konsep Waterballast Treatmen Memanfaatkan Gas Inert Temperatur Tinggi dari Gas Buang Mesin Induk untuk Mengurangi Mikroorganisme Air Ballast pada Kapal,” Jurusan Teknik Sistem Perkapalan, Surabaya, 2014. 